\title{
Ergenlerde Şiddet Eğiliminin Yordayıcıları Olarak Sosyal Kaygı ve Duygusal Özerklik*
}

\section{Social Anxiety and Emotional Autonomy as Predictors of Violence Tendency in Adolescents}

\author{
Suat KILIÇARSLAN**, İzzet PARMAKSIZ***
}

\begin{abstract}
Öz: Bu araştırmada sosyal kaygı ve duygusal özerkliğin ergenlerin şiddet eğilimlerini yordama gücü incelenmiştir. Araştırma, 2018-2019 eğitim-öğretim yılında Orta Anadolu'da bir ilde öğrenimlerine devam eden ve yaşları 13 ve 17 arasında değişmekte olan öğrenciler ile yürütülmüş̧tür. Araştırmaya 317 (\%51) kız ve 296 (\%49) erkek olmak üzere toplam 613 öğrenci katılmıştır. Araştırmanın verileri Ergenler İçin Sosyal Kaygı Ölçeği, Duygusal Özerklik Ölçeği, Şiddet Eğilimi Ölçeği ve araştırmacılar tarafından oluşturulan demografik bilgi formu kullanılarak toplanmıştır. Araştırmanın bulguları incelendiğinde, sosyal kaygı ölçeği alt boyutu olan 'olumsuz değerlendirilme korkusu' ile şiddet eğilimi puanları arasında pozitif yönde anlamlı bir ilişki olduğu görülürken; Duygusal Özerklik Ölçeğinin 'ebeveyni idealleştirmeme', 'ebeveynden bağımsızlık' ve 'bireyleşme' alt boyutları ile şiddet eğilimi puanları arasında negatif yönde anlamlı ilişkiler olduğu görülmüştür. Bununla birlikte; araştırmaya katılan ergenlerin şiddet eğilimi puanlarının cinsiyete ve anne-baba eğitim düzeyine göre farklılaştığı görülmüştür. Sonuç olarak, ergenlerin cinsiyet ve anne-baba eğitimi gibi sosyo-demografik bilgileri, sosyal kaygı ölçeği alt boyutu olan 'olumsuz değerlendirilme korkusu' ve duygusal özerklik ölçeği alt boyutları olan 'ebeveyni idealleştirmeme', 'ebeveynden bağımsızlık' ve 'bireyleşme' alt boyutlarının birlikte şiddet eğiliminin anlamlı yordayıcıları olduğu saptanmıştır. Bu sonuçlar bireyin kimlik gelişiminde kritik bir gelişim sürecini ifade eden ergenlik döneminde şiddet eğilimini kontrol etmeleri konusunda, sosyal kaygıları ile baş edebilmeleri ve ailesinden bağımsızlaşma ihtiyacını giderebilmesinde duygusal özerklik sağlayabilmelerinin çok önemli olduğunu göstermektedir.
\end{abstract}

Anahtar Kelimeler: Ergenlik, sosyal kaygı, duygusal özerklik, şiddet

\begin{abstract}
In this study, the prediction power of social anxiety and emotional autonomy over adolescents' violence tendencies was examined. The study was carried out with students (aged between 13 and 17) who were attending school in a city center in Central Anatolia during the 2018-2019 academic year. A total of 613 students, 317 females and 296 males, participated in the study. The study data was collected using 'Social Anxiety Scale for Adolescents', 'Emotional Autonomy Scale', 'Violence Tendency Scale' and 'Personal Information Form', developed by the researchers. According to the study findings, while there was a positive significant relationship between the 'Fear of Negative Evaluation' sub-dimension of Social Anxiety Scale for Adolescents and violence tendency scores, there were negative significant relationships between 'Parental Deidealization', 'Nondependency on Parents' and 'Individuation' sub-dimensions of Emotional Autonomy Scale and violence tendency scores. However; the participating adolescents' violence tendency scores varied according to sex and mother-father education level. As a result, it was determined that the socio-demographic information of adolescents such as sex and mother-father education level, 'fear of negative evaluation' sub-dimension of social anxiety scale, and 'parental deidealization' and 'nondependency on parents' and 'individuation' sub-dimensions of the emotional autonomy scale were all significant predictors of violence tendency. These results show that it is very important for the individual to realize emotional autonomy in controlling the violence tendency, coping with social anxieties and
\end{abstract}

\footnotetext{
* Bu araştırma, 24-27 Ekim 2019 tarihlerinde Antalya'da düzenlenen 21. Uluslararası Psikolojik Danışma ve Rehberlik Kongresinde (PDRkongre2019) özet sözlü bildiri olarak sunulmuştur.

** Dr. Öğr. Üyesi, Niğde Ömer Halisdemir Üniversitesi, Eğitim Fakültesi, Niğgde-Türkiye, ORCID:0000-0002-29078480, e-posta: suatkilicarslan@hotmail.com

*** Dr. Öğr. Üyesi, Niğde Ömer Halisdemir Üniversitesi, Eğitim Fakültesi, Niğde-Türkiye, ORCID: 0000-0003-24686134, e-posta: izparm44@gmail.com
} 
achieving individuation from family during adolescence, a critical development period in the identity development of an individual.

Keywords: Adolescence, social anxiety, emotional autonomy, violence

\section{Giriş}

Bireylerin gelişim sürecindeki en önemli aşamalardan biri olan ergenlik dönemi, pek çok değişimi içeren kritik bir süreçtir. Bu dönemde fiziksel, zihinsel ve duygusal farklilaşmalara uyum sağlamasının yanı sıra bireyin toplumsal ve sosyal alanda da bir kimlik duygusu geliştirmesi beklenmektedir. Ergenlik, kimlik kazanımı, özerklik duygusu, çevreyle yakın ve özel ilişkiler kurma, bulunduğu toplum içinde iyi bir konuma sahip olma dönemi olarak ifade edilmektedir (Steinberg, 2007). Ergenlik döneminde ortaya çıkan biyolojik ve psikolojik değişimler ile çocukluktan yetişkinliğe geçişte gösterdikleri davranışlar bireyin yaşıtları tarafından kabul edilmesini, anne-babadan ayrışmasını, geleneksel değerlere karşı çıkmasını, engellenmeler ve kaygıları ile başa edebilmesini, kimlik kazanımını ve böylelikle bireyin olgunlaşmasını sağlamaktadır (Peterson ve diğerleri, 2003).

Ergenler, bu gelișim sürecinde meydana gelen biyolojik, zihinsel, duygusal ya da sosyal değişimlere uyum sağlamakta ve çevresi ile sağlıklı ilişkiler geliştirmekte zorlanarak bazı yıkıcı davranışlar sergileyebilmektedir (Henning, Leitenberg, Coffey, Bennett ve Jankowski, 1997; Silvern, Karly, Waelde, Hodges ve Starek, 1995). Dünyada ve Türkiye'de, son yıllarda şiddet olaylarında önemli bir artış vardır ve toplumsal açıdan yaşanan şiddet olayları günümüzün en önemli problemlerden biri haline gelmiştir. Dünya Sağlık Örgütü’ne (WHO, 2002) göre, “Şiddet, bireyin kendisine, başkasına, belirli bir topluluğa veya gruba yönelik yaralama, ölüm, fiziksel zarar, bazı gelişim bozuklukları veya yoksunluk ile sonuçlanabilen tehdit ya da fiziksel zor kullanması" olarak belirtilmektedir.

Gordon (1999) ergenlerin bilhassa engellendiklerinde ve anlaşılamadıklarını düşündüklerinde tepkili olduklarını; otorite figürlerini düşman gibi görebildiklerini ve bunun sonucunda şiddet eğilimi gösterdiklerini ifade etmektedir. Ergenlik döneminde riskli davranışlar, madde kullanımı, şiddet, ergen cinselliği, antisosyal özellik taşıyan duygusal ve davranışsal sorunlar sıklıkla karşımıza gelmektedir (Pathak ve diğgerleri, 2011). Bu açıdan bakıldığında kritik bir gelişim süreci olan ergenlikte yaşanan problemlerle baş etmedeki zorluklar bireyi stres altına almakta olup, şiddet davranışlarının ortaya çıkmasında belirleyici olmaktadır.

Ergenlike bireyin kendisi ve çevresiyle olan etkileşimlerinde yoğun olarak yaşadığ 1 problemlerinden birisi de sosyal kaygıdır. Sosyal kaygı, toplum içinde kendini ifade etme, yemek yeme, birileriyle tanıştırılma, yeni bir ortamda bulunma gibi özel durumlardan ya da tüm sosyal ortamlardan kaçınma olarak kendini gösterebilmektedir. Ergenler sosyal ortamlarda utanma, çekinme, geri çekilme ya da güvensizlik gibi zorlayıcı duygular yaşayabilmektedir. Amerikan Psikiyatri Birliği (2013) tanı ölçütleri başvuru el kitabında (DSM 5) sosyal kayg1, "Bireyin tanımadığı insanlarla karşılaştığı ya da başkalarının gözünün üzerinde olabileceği, bir ya da birden fazla toplumsal ya da bir eylemi gerçekleştirdiği durumdan, belirgin ve sürekli bir korku duyma. Kişinin küçük düşeceği ya da utanç duyacă̆ı bir biçimde davranacă̆ından korkması" şeklinde tanımlanmıştır. Beck (2005) sosyal kaygıyı bireyin dikkat çekmeye ve diğer bir insanlar tarafından olumsuz değerlendirilmeye, değersiz görülmeye karşı yaşadığı duygu durumu olarak açıklamıştır. Son yıllardaki araştırmalarda, özellikle çocuk ve ergenlerin yaşadıkları sosyal kaygının araştırılması ve tedavi alternatiflerinin belirlenmesine yönelik çalışmalar giderek çoğalmaktadır (Pineles ve Mineka, 2005). Ergenlerin günlük yaşamlarında sürekli iletişim ve etkileşim içerisinde olmaları önemli bir sosyal ihtiyaçtır (Lee, 2009). Bunun yanı sıra ergenler bu dönemin özelliklerinden dolayı eleştirilme, küçük düşme ve hata yapma korkusu yaşayabilmektedirler ve bu durum da sosyal kaygıyı ortaya çıkarabilir (Mehtalia ve Vankar, 2004; Tassin, Reynaert, Jacques ve Zdanowicz, 2014). Ergenlik döneminde sosyal kayg1 yaşama olasılığı yüksektir (Hamarta, 2009) ve ergenler başkaları tarafından değerlendirilmekten çoğunlukla çekinirler (Kashdan, 2007). Erath, Flanagan ve Bierman (2007), ergenlikte sosyal kaygıya neden olan faktörleri incelemiş ve artan akran mağduriyeti ve azalan akran kabulü ile sosyal kaygı arasında yüksek ilişki saptamıştır. Alanyazın incelendiğinde, ergenlerde sosyal kaygı 
ile birlikte alkol kullanımının, akademik başarının düşüklüğünün, depresyon vb. psikolojik problemlerin, davranışsal sorunların ve psikotik semptomların görüldüğünü saptayan pek çok araştırma mevcuttur (Cruz, Martins ve Diniz, 2017; Pontillo ve diğerleri, 2017). Ergenlik dönemi özellikleri düşünüldüğünde ergenlerin olumsuz değerlendirilmekten kaygı duydukları ve sosyal ortamlarda farklı davranış kalıpları içerisine yönelebileceği düşünülerek bu araştırmada sosyal kaygı ve şiddet eğilimi arasındaki ilişkilere de odaklanılmıştır. Dolayısıyla ergenlerin sosyal kaygı düzeyinin yüksek olması pek çok olumsuz davranışın ortaya çıkmasında olabileceği gibi saldırganlık ve şiddet gibi yıkıcı davranışlarda da rol oynayabileceği düşünülmektedir.

Ergenlik dönemindeki bireylerin sosyal ve psikolojik uyumu açısından önemli olan bir başka faktör de duygusal olarak özerk olabilme becerileridir. Ergenlerin sağlıklı bir birey olabilmesi için önemli gelişim görevlerinden birisi olan özerklik kimlik gelişimi açısından çok önemlidir (Noom, Dekovic ve Meeus, 2001). Özerklik, aileyle iletişimin devam ettiği, fakat bireyin kendi kararlarını verebildiği bir gelişim sürecidir (Collins, Gleason ve Sesma, 1997). Duygusal özerklik daha çok aileden bağımsızlaşma ve bireyleşme, çevreye göre değil, kendi istekleri doğrultusunda karar alabilme ve ergen bireyin kendine güven duyması olarak ifade edilir (Noom, Dekovic ve Meeus, 2001; Steinberg ve Silverberg, 1986). Zimmer-Gembeck'e (2001) göre, ergenlerde sağlıklı bir ruhsal gelişim ve benlik algısı için duygusal özerkliğin gelişmesi oldukça önemlidir. Lamborn ve Steinberg (1993) duygusal özerkliğin gelişim açısından ergenler için olumlu sonuçlarla ilişkili olduğunu ve riskli ortamlarda ise; olumsuzluklardan koruduğunu ifade etmişlerdir. Bu anlamda ergenlik, özerklik gelişiminin sağlanabildiği yaşam dönemi olarak ifade edilebilir ve sağlıklı özerklik gelişimi ergenin ruh sağlı̆̆ açısından içe kapanma, sosyal izolasyon ve yalnızlık ya da suç ve şiddet içeren yıkıcı bazı davranışlardan uzak kalmalarına yardımcı olabilir. Alanyazın incelendiğinde, duygusal özerkliğin akran baskısı, özgüven, okul başarısı, psikolojik sıkıntı, ebeveynlik stilleri, ebeveyn-çocuk iletişim kalıpları, depresyon semptomları, öznel iyi oluş, yaşam doyumu, iletişim, benlik saygısı, intihar davranışı ve sosyal destek düzeyi gibi bazı değişkenlerle ilişkisini inceleyen çalışmalara rastlanmamakla birlikte duygusal özerklik, sosyal kaygı ve şiddet eğilimi arasındaki ilişkilere odaklanan çalışmaların olmadığı görülmektedir.

Ergenlik döneminde bireyin anne-babadan bağımsızlaşarak sağlıklı bir özerklik duygusunun gelişimi, bununla birlikte sosyal kaygı ve şiddet eğilimi gibi problemleri ortaya çıkaran faktörlerin belirlenmesi bu doğrultuda yapılacak önleme ve müdahale çalışmaları açısından önem taşımaktadır. Ergen bireyin çok yönlü ve sağlıklı bir gelişim süreci geçirebilmesi açısından bu çalışmanın sonuçlarının ebeveynlere, eğitimcilere, alanda çalışan psikolojik danışmanlara ve araştırmacılara katkı sağlayacağı düşünülmektedir. Bu çerçevede, bu araştırmada ergenlerin sosyal kaygı, duygusal özerklik ve şiddet eğilimi düzeyleri arasındaki ilişkiler incelenmiştir. Bu genel amaç doğrultusunda bu çalışmada aşağıdaki hipotezler test edilmiştir:

1. Ergenlerin yaşadığı sosyal kaygı, duygusal özerklik ve şiddet eğilim düzeyleri arasında anlamlı bir ilişski vardır.

2. Ergenlerin sosyal kaygı düzeyi şiddet eğilimini pozitif yönde anlamlı bir şekilde yordayacaktır.

3. Ergenlerin duygusal özerklik düzeyi şiddet eğilimini negatif yönde anlamlı bir şekilde yordayacaktır.

\section{Yöntem}

Bu araştırmada ergenlerin sosyal kaygı, duygusal özerklik ve şiddet eğilimi ilişkisini incelemeye yönelik ilişkisel tarama modeli kullanılmıştır. İlişkisel tarama modelleri, iki ve daha çok sayıdaki değişken arasında birlikte değişim varlığını veya bu değişimin derecesini belirlemeyi amaçlayan araştırmalarda kullanılır (Karasar, 2005). Bu doğrultuda ergenlerin şiddet eğilimi düzeylerinin, sosyal kaygı, duygusal özerklik, cinsiyet ve anne-baba eğitim durumu gibi sosyodemografik değişkenlerle ilişkisi betimlenmeye çalışılmıştır. 


\section{Çalışma grubu}

Araştırmanın örneklemini, 2018-2019 eğitim öğretim yılında Niğde İli merkez ilçesinde öğrenimlerine devam eden ve yaşları 13 ve 17 arasında değişmekte olan (Ort $\pm \mathrm{Ss}=14,91 \pm 0,93$ ) 7., 8., 9. ve 10. sınıf öğrencileri oluşturmaktadır. Araştırmaya 317 (\%51) kız ve 296 (\%49) erkek olmak üzere 613 öğrenci katılmıştır.

\section{Veri toplama araçları}

Şiddet Ĕgilim Ölçeği: Şiddet eğilimi ölçeği liselerde öğrenim gören öğrencilerin saldırganlık ve şiddet eğilimlerini tespit etmek amacıyla Başbakanlık Aile Araştırma Kurumu Başkanlığı (1998) tarafından yürütülen proje çerçevesinde "Orta Öğretim Kurumlarında Okuyan Öğrencilerin Saldırganlık ve Şiddet Eğilimleri" konulu araştırmada kullanılmak üzere Göka, Bayat ve Türkçapar (1995) tarafından geliştirilmiştir. Ölçek, 20 maddeden oluşmaktadır ve ölçekte ters puanlanan madde yoktur. Ölçek 4'lü likert tipindedir. Ölçek toplam puan alınarak değerlendirilmektedir. 1-20 arasındaki puan şiddet eğilimi “çok az", 21-40 arasında ise "az"; 4160 arasında ise "fazla", 61-80 arasında "çok fazla" şiddet eğiliminde olduğu şeklinde yorumlanmıştır. Ölçekten alınan puanlar yükseldikçe şiddet eğilimi de yüksek olarak yorumlanmaktadır. Geçerlik ve güvenirlik çalışması için Taşkesen (2011) ölçeğin iç tutarlık değeri .76 olarak hesaplamıştır. Yapı geçerliği için yapılan faktör analizinde en yüksek faktör yüküne sahip madde .805 faktör yükü ile 15. madde iken 18 . madde en düşük faktör yüküne sahip maddedir ve yük değeri, .423 olduğu saptanmıştır. Bu araştırmada ölçeğin içtutarlık katsayısı .84 olarak hesaplanmıştır.

Duygusal Özerklik Ölçeği: Steinberg ve Silverberg (1986) tarafindan geliştirilen Duygusal Özerklik Ölçeği Deniz, Çok ve Duyan (2013) tarafından Türkçe'ye uyarlanmıştır. Ölçek toplam 14 maddeden oluşmaktadır. Ölçek 4'lü likert tipindedir, alt ölçek puanları ve toplam puanı hesaplanabilmektedir. Ölçeğin güvenirlik çalışması kapsamında ölçek toplam puanı için iç tutarlılık kat sayıs1 .79, idealleştirmeme alt ölçeği için .71, bağımsızlık alt ölçeği için .64 ve bireyleşme alt ölçeği için .67 olarak bulunmuştur. Yapı geçerliği için yapılan doğrulayıcı faktör analizi sonucunda ölçek yapısının doğrulandığı görülmüştür. Ana-babayı birey olarak görme alt ölçeği önceki çalışmalarda duygusal özerkliğe katkısının az olması ve madde toplam korelasyonlarının istenen düzeyde olmamasından dolayı faktör analizi kapsamına alınmamıştır. Üç faktörlü yapı doğrulayıcı faktör analizinde doğrulanmıştır ve madde uyum indekslerinin kabul edilebilir düzeyde olduğu görülmüştür. Böylece, uyarlanma sonucunda toplam 14 maddeden oluşan üç alt ölçek bulunmaktadır. Yapılan analizler sonucunda ölçeğin güvenilir ve geçerli bir ölçek olduğu değerlendirilmiştir. Bu araştırmada da ölçeğin iç tutarlık katsayısı toplam puan için .78 , bağımsızlık alt ölçeği için .54, idealleştirmeme alt ölçeği için .68 , bireyselleşme alt ölçeği için .65 'tir.

Ergenler için Sosyal Kaygı Ölçeği: Greca (1999)'un gelitirdiği ölçek Aydın ve Tekinsav-Sütçü (2007) tarafından Türk kültürüne uyarlanmıştır. Ölçek, 18 maddeden oluşmaktadır. Ölçeğin olumsuz değerlendirilme korkusu (ODK), genel durumlarda sosyal kaçınma-huzursuzluk duyma (G-SKHD) ve yeni durumlardan sosyal kaçınma-huzursuzluk duyma (Y-SKHD) olmak üzere üç alt boyutu vardır. Ölçeğin toplam puanı ile ODK alt ölçeği arasında .89; G-SKHD alt ölçeği arasında .75 ve Y-SKDH alt ölçeği arasında .85 düzeyinde anlamlı ilişki saptanmış. Ölçeğin iç tutarlık katsayısı .88 ve iki yarım güvenirlik katsayısı $.85^{\prime}$ tir. Ölçeğin geçerlik çalışması için Çapa Çocuk ve Ergenler için Sosyal Fobi Ölçeği ile .77 ve Çocuklar için Durumluk Sürekli Kayg1 Envanteri ile .66 düzeyinde ilişki olduğu belirlenmiştir. Bu araştırmada da ölçeğin içtutarlık katsayısı toplam puan için .87 , olumsuz değerlendirilme korkusu .84 , genel durumlarda sosyal kaçınma-huzursuzluk duyma alt ölçeği için .69 ve yeni durumlardan sosyal kaçınma-huzursuzluk duyma için .66 olarak hesaplanmıştır. 
Demografik Bilgi Formu: Araştırmacılar tarafından oluşturulan demografik bilgi formu çerçevesinde katılımcıların cinsiyet ve anne-baba eğitim durumu gibi bilgilerden oluşmaktadır.

\section{İşlem}

Araştırma verileri Niğde İl Milli Eğitim Müdürlüğü’den alınan 02.05.2019 tarihli ve 61900286604.01.01-E.8715979 sayılı izinle toplanmıştır. Araştırma sürecinde araştırma ve yayın etiğine uyulmuştur. 2018-2019 eğitim öğretim yılı ikinci döneminde belirlenen ölçekler araştırmacılar tarafından öğrencilere uygulanmıştır. Ölçeklerin uygulanması sırasında okul idarecileri ve okul psikolojik danışmanı ile görüşülerek ölçekler öğrencilere kendi sınıflarında ve rehberlik saatlerinde uygulanmıştır. Bu işlem ortalama otuz dakika sürmüştür.

\section{Verilerin analizi}

$\mathrm{Bu}$ araştırma kapsamında sosyal kayg1 ve duygusal özerkliğin ergenlerin şiddet eğilimlerini yordama gücü incelenmiştir. Çarpıklık değeri tüm değişkenler için -.23 ile .80 aralığındadır; basıklık değeri ise tüm değişkenler için -.44 ile .33 aralığındadır. Huck (2008) skewness değerlerinin \pm 1 civarında kurtosis değerlerinin de $-1,+2$ aralığında olmasının da istatistiksel olarak normal olduğunu belirtmektedir. Değişkenler arasındaki ilişkiyi belirlemek için Pearson Momentler Çarpım Korelasyon Katsayısı ve Hiyerarşik Regresyon Analizi istatistiksel analiz tekniklerinden yararlanılmıştır. Veriler aykırı değer açısından incelenip 0.001 manidarlık düzeyi dikkate alınmış (Büyüköztürk, 2014) Mahalanobis uzaklık değerine göre bakıldığında aykırı değere sahip veri olmadığı görülmüştür. Tolerans $>0.2$ ve $\mathrm{VIF}<10$ değerlerinde olmas 1 kabul edilir değerlere sahip olduğunu göstermektedir (Green ve Salkınd, 2010). Otokorelasyonu test etmede kullanılan Durbin-Watson testinin 1.5-2.5 aralığında olması gereken değeri (Kalayc1, 2010) bu araştırmada 1.91 'dir.

\section{Bulgular}

Araştırmada ilk olarak katılımcıların şiddet eğilimi düzeylerinin cinsiyet ve anne-baba eğitim düzeyine göre farklılaşıp farklılaşmadığına bakılmıştır. Araştırmanın bağımsız değişkenlerine ilişkin bulguları incelendiğinde, ilk olarak öğrencilerin şiddet eğilimi ölçeği puanları cinsiyete ( $\mathrm{t}=$ $-3,795 ; p<.001)$, anne eğitim düzeyine $(\mathrm{F}=3,908 ; p<.05)$ ve baba eğitim düzeyi'ne $(\mathrm{F}=6,952$; $p<.001)$ göre anlamlı bir şekilde farklılaştığı görülmüştür. Bu bulgulara göre, erkek ergenlerin şiddet eğilim düzeyleri kızlara göre daha yüksektir. Anne-baba eğitim düzeyi açısından bakıldığında ise, anne-babaları üniveriste mezunu olan ergenlerin şiddet eğilimi puanları diğer eğitim seviyelerine göre daha düşük olduğu saptanmıştır.

\section{Ergenlerin yaşadığı sosyal kaygı, duygusal özerklik ve şiddet eğilim düzeyleri arasında ilişkilere ilişskin bulgular}

Araştırmada ikinci olarak ergen bireylerin sosyal kaygı düzeyleri, duygusal özerklik ve şiddet eğilimi puanları arasındaki ilişkiler incelenmiş olup sonuçlar Tablo 1'de verilmiştir.

Tablo 1.

Ergenlerin Sosyal Kaygı Düzeyleri, Duygusal Özerklik Düzeyleri ve Şiddet Eğilimi Ölçeği Puanları Arasındaki İlişkiye İlişkin Pearson Momentler Çarpımı Korelasyon Katsayıları

\begin{tabular}{|c|c|c|c|c|c|c|c|}
\hline Ölçekler ve Alt Boyutları & 1 & 2 & 3 & 4 & 5 & 6 & 7 \\
\hline 1. Şiddet Eğilimi Ölçeği & 1 & & & & & & \\
\hline ESKÖ & & & & & & & \\
\hline $\begin{array}{l}\text { 2. Olumsuz Değerlendirilme } \\
\text { Korkusu }\end{array}$ & $.115^{* *}$ & 1 & & & & & \\
\hline $\begin{array}{l}\text { 3. Genel Durumlarda Sosyal } \\
\text { Kaçınma }\end{array}$ & .049 & $.518^{* *}$ & 1 & & & & \\
\hline $\begin{array}{l}\text { 4. Yeni Durumlardan Sosyal } \\
\text { Kaçınma }\end{array}$ & -.059 & $.500^{* *}$ & $.650^{* *}$ & 1 & & & \\
\hline
\end{tabular}




\begin{tabular}{llllllll}
\hline EDÖ & & & & & & & \\
5. Bağımsızlık & $-.141^{* *}$ & .060 & .051 & $.121^{* *}$ & 1 & & \\
6. İdealleştirmeme & $-.213^{* *}$ & $.089^{*}$ & .063 & $.142^{* *}$ & $.511^{* *}$ & 1 & \\
7. Bireyselleşme & $-.337^{* *}$ & $-.161^{* *}$ & $-.115^{* *}$ & .012 & $.370^{* *}$ & $.357^{* *}$ & 1 \\
\hline
\end{tabular}

ESKÖ: Ergenlerde sosyal kaygı ölçeği

EDÖ: Ergenlerde duygusal özerklik ölçeği

Tablo 1 incelendiğinde; öğrencilerin şiddet eğilimi puanları ile sosyal kaygı ölçeği alt boyutu olan olumsuz değerlendirilme kaygısı $(r=.115 ; \mathrm{p}<.001)$ arasında pozitif yönde anlamlı bir ilişki bulunurken, duygusal özerklik ölçeği toplam puanı $(r=-.300 ; p<.001)$, ve bağımsızlık $(r=-.141 ; p<.001)$, idealleştirmeme $(r=-.213 ; p<.001)$ ve bireyleşme alt ölçeği $(r=-.337 ; p<.001)$ puanları arasında negatif yönlü anlamlı bir ilişki olduğu görülmüştür. Bu sonuçlara göre, ergenlerin olumsuz değerlendirilme korkusu arttığında şiddet eğilimleri de artmakta; bağımsızlık, idealleştimeme ve bireyselleşme puanları arttığında ise şiddet eğilimi puanları azalmaktadır.

Ergenlerde cinsiyet, anne-baba eğitimi, sosyal kaygı ve duygusal özerklik düzeyinin şiddet eğilimini yordamasına ilişkin regresyon analizi sonuçları

Yapılan ön analiz sonucunda, öğrencilerin cinsiyet ve anne-baba eğitim düzeyine göre şiddet puanları anlamlı düzeyde farklılaştı̆̆ için bu değişkenler dummy değişken olarak tanımlanmıştır ve korelasyon analizinde şiddetle anlamlı ilişkiye sahip değişkenlerin şiddet eğiliminin anlamlı bir yordayıcısı olup olmadığına hiyerarşik regresyon analizi ile bakılmıştır. Sosyal kaygı ölçeği alt boyutları olan 'genel durumlardan sosyal kaçınma' ve yeni durumlardan sosyal kaçınma' ile şiddet eğilimi arasında anlamlı düzeyde bir ilişki olmadığı için bu alt boyutlar regresyon analizine dahil edilmemiştir. Sonuçlar Tablo 2'de verilmiştir.

Tablo 2.

Ergenlerde Cinsiyet, Anne-Baba Eğitimi, Sosyal Kaygı ve Duygusal Özerklik Düzeyinin Şiddet Eğilimini Yordamasına Ilişkin Regresyon Analizi Sonuçları

\begin{tabular}{|c|c|c|c|c|c|c|c|}
\hline \multirow[t]{5}{*}{$\begin{array}{l}\text { Bağımlı } \\
\text { Değişken }\end{array}$} & & Bağımsız Değişken & $\mathrm{R}^{2}$ & $\mathrm{~F}$ & B & Beta & $\mathrm{t}$ \\
\hline & \multicolumn{7}{|l|}{1} \\
\hline & & Cinsiyet & & & 2,89 & .143 & $3,57 *$ \\
\hline & & Anne_Eğitim & .03 & $6,93^{*}$ & .68 & .029 & .69 \\
\hline & & Baba_Eğitim & & & 2,08 & .086 & $2,02 * * *$ \\
\hline \multirow{14}{*}{ Şiddet } & 2 & & & & & & \\
\hline & & Cinsiyet & & & 3,10 & .153 & $3,84^{*}$ \\
\hline & & Anne_Eğitim & & & .55 & .024 & .56 \\
\hline & & Baba_Eğitim & .05 & $7,93^{*}$ & 2,20 & .091 & $2,15^{* * *}$ \\
\hline & & Olumsuz_Değerlendirilme & & & .23 & .129 & $3,25 * *$ \\
\hline & & Korkusu & & & & & \\
\hline & \multirow[t]{8}{*}{3} & & & & & & \\
\hline & & Cinsiyet & & & 2,97 & .147 & $3,85^{*}$ \\
\hline & & Anne_Eğitim & & & .58 & .025 & .63 \\
\hline & & Baba_Eğitim & & & 2,71 & .112 & $2,81 * *$ \\
\hline & & $\begin{array}{l}\text { Olumsuz_Değerlendirilme } \\
\text { Korkusu }\end{array}$ & .17 & $6,93^{*}$ & .17 & .095 & $2,48 * * *$ \\
\hline & & Özerklik_Ebeveyn_İdeal & & & -.06 & -.020 & -.43 \\
\hline & & Özerklik_Ebeveyn_Bağımsızlık & & & -.43 & -.112 & $-2,50 * * *$ \\
\hline & & Özerklik Bireyleșme & & & -.83 & -.280 & $-6,68^{*}$ \\
\hline
\end{tabular}

$* \mathrm{p}<0,001, * * \mathrm{p}<0,01, * * * \mathrm{p}<0,05$ 
Yapılan hiyerarşik regresyon analizi sonuçlarına göre cinsiyet ve anne-baba eğitim düzeyi birlikte ergenlerin şiddet eğilimini $\% 3$, cinsiyet, anne-baba eğitim düzeyi ve olumsuz değerlendirilme korkusunun birlikte ergenlerin şiddet eğilimini \% 5 yordadığı saptanmıştır. Son olarak ergenlerinlerin cinsiyet ve anne-baba eğitim düzeyi, sosyal kaygı ölçeği alt boyutu olan 'olumsuz değerledirilme korkusu' ve duygusal özerklik ölçeği alt boyutları olan 'ebeveyni idealleştirmeme', 'ebeveynden bağımsızlık' ve 'bireyleşme' birlikte öğrencilerin şiddet eğilimini $\% 17$ yordadığı görülmüştür. $\mathrm{R}^{2}$ değeri $0.02 \leq \mathrm{R}^{2}<0.13$ iken küçük etkiyi, $0.13 \leq \mathrm{R}^{2}<0.26$ iken orta etkiyi, $0.26 \leq \mathrm{R}^{2}$ ise büyük bir etkiyi ifade etmektedir (Cohen, 1988). Bu sonuçlara bakılarak yapılan analizin 1. ve 2. adımında bağımsız değişkenlerin bağımlı değişken üzerinde küçük bir etki, 3. adımında ise orta düzeyde bir etki oluşturduğu saptanmıştır.

\section{Tartıșma, Sonuç ve Öneriler}

Bu çalışmada sosyal kaygı ve duygusal özerkliğin ergenlerin şiddet eğilimlerini yordama gücü incelenmiştir. Yapılan ön analizlerde, erkek ergenlerin şiddet eğilimi puanlarının kızlara göre daha yüksek olduğu bulunmuştur. Türkiye' de ve dünyada ergen bireyler üzerinde yapılan pek çok çalışmada erkek öğrencilerin şiddet eğilimlerinin kız öğrencilere göre daha yüksek olduğu görülmüştür (Avc1, 2010; Balkıs, Duru ve Buluş, 2005; Durmuş ve Gürgan, 2005; Gençoğlu, Kumcağız ve Ersanlı 2014; Giles ve Heyman, 2005; Lopez ve Emmer 2002; Sağlam ve İkiz, 2017; Scharf, 2000; Thomas ve Smit 2004; Yavuzer, 2013). Aral, Ayhan, Türkmenler ve Akbıyık (2004) de farklı sosyo-ekonomik düzeyden öğrencilerin cinsiyet, sosyo-ekonomik düzey, annebabanın eğitim seviyesi, öğrencilerin arkadaşlarına kızmasına verdiği tepkiye göre saldırganlık puanlarının anlamlı farklılaştığını bulmuşlardır. Toplumsal araştırma ve gözlemler dikkate alındığında, yukarıdaki araştırma sonuçlarında da görüldüğü üzere kadın ve erkeklere atfedilen toplumsal cinsiyet rollerinin kızların uyumlu davranma konusunda daha fazla baskı hissettikleri ve kızgınlıklarını ifade etmekten çekindikleri; erkek ergenlerin ise kızgınlıklarını ifade etmede onaylandıkları şeklinde ifade edilebilir. Ayrıca şiddet, toplum tarafından paylaşılan bir değer olarak ve kuşaktan kuşağa aktarılarak bazı kültürlerce desteklenmektedir. Bu durum ise şiddetin sosyal bir nedeni olarak düşünlebilir (Rynerson, 1997). Araştırma bulgularındaki bu farklılığın kültürel faktörler ve toplumsal cinsiyet rolleri ile açıklanabileceği söylenebilir.

Anne-baba eğitim düzeyi açısından bulgular değerlendirildiğinde ergenlerin şiddet eğilimi düzeyleri anne-baba eğitim düzeyine göre farklılaşmaktadır. Alanyazında anne-baba eğitim düzeyi düşük ergenler arasında şiddet eğiliminin görülme sıklığının fazla olduğunu gösteren araştırmalar olduğu gibi, anne-baba eğitim düzeyi ile ergenin şiddet eğilimi arasında anlamlı bir ilişki olmadığını gösteren araştırmalar da bulunmaktadır. Örneğin; Avcı'nın (2006) çalışmasına göre annesinin eğitim seviyesi düşük olan ergenler arasında şiddet içerikli davranışlar daha yaygındır. Ayan (2007) ve Kula'nın (2008) araştırmalarında ise, saldırganlık puanlarının annenin eğitim düzeyine göre anlamlı farklılaşmadığını saptamıştır. Ayrıca Karataş (2002) şiddete başvuran ergenlerin baba eğitim düzeylerinin şiddete başvurmayanlara göre daha düşük olduğunu bulmuştur. Yılmaz (2008) tarafından gerçekleştirilen araştırmanın sonuçlarına göre ise, anne baba eğitim durumunun öğrencilerin şiddet davranışının farklılaşmasına istatistiksel olarak etki etmediği görülmüştür.

Araştırma bulguları şiddet eğilimi puanlarının ergenlerin sosyal kaygı ölçeği alt boyutu olan 'olumsuz değerlendirilme korkusu' ile pozitif, duygusal özerklik alt ölçekleri olan 'bağımsızlık, idealleştirmeme ve bireyselleşme' ile ise negatif yönde anlamlı bir ilişkisi olduğunu göstermektedir. Bu bağlamda ergenlerin yaşamış olduğu olumsuz değerlendirilme korkusunun şiddet eğilimini artırdığı, bağımsızlık, idealleştirmeme ve bireyselleşmenin ise şiddet eğilimini azalttığ1 söylenebilir. Aynı zamanda cinsiyet ve anne-baba eğitim düzeyi gibi sosyodemografik değişkenler ile birlikte, sosyal kaygı ölçeği alt boyutu olan 'olumsuz değerlendirilme korkusu' ve duygusal özerklik ölçeği alt boyutları olan 'ebeveyni idealleştirmeme', 'ebeveynden bağımsızlık' ve 'bireyleşme' alt boyutlarının birlikte ergenlerde şiddet eğiliminin önemli yordayıcıları olduğu saptanmıştır.

Alanyazın incelendiğinde şiddet eğiliminin ortaya çıkmasına neden olan pek çok sebep olduğu ve farklı yaklaşımların şiddet eğilimini farklı boyutlarıyla ele aldığı görülmektedir. 
Ergenlik döneminde, ergenin gelişim sürecinde meydana gelen değişimlerle ile ilişkili olarak şiddet davranışlarında bir artış olduğu belirtilmektedir. Sosyal kaygı açısından bakıldığında, ergenlerin başarmaları gereken gelişim görevleri ergenlik döneminin, sosyal kaygının oluşumunda riskli bir dönem olduğunu göstermektedir (Albano ve Hayward, 2004). Sosyal kaygısı olan bireyler, sosyal ortamlarda diğerleri üzerinde olumsuz bir izlenim birakacaklarını, diğerleri tarafından eleştirileceklerini veya bir hata yapacaklarını düşünerek tehlike beklentisi içine girerler ve sosyal ortamların tehlikeli olduğuna dair inanç geliştirirler. Bu çerçevede, kaygıdan kurtulmak için bazı kaçınma ve güvenlik davranışları geliştirebilirler (Wells, 2009). Diğerleri tarafindan beğenilmeme kaygısı yaşayan ve eleştirilere maruz kalacağını düşünen bir kişi sosyal ortamları tehlike olarak algılayabilirler. Tehlikeli olarak algılanan durumlarda kişi, tehlike anında vereceği bedensel tepkiler veya kaçınma davranışları geliştirebilir. Bu araştırmanın sonuçlarına benzer şekilde, Wenzel, Graff-Dolezal, Macho ve Brendle (2005) de yapmış oldukları çalışmada sosyal kaygısı yüksek olan bireylerin diğerlerine göre daha fazla "olumsuz davranış", daha az "olumlu davranış" sergilediği sonucuna ulaşmışlardır.

Alanyazın incelendiğinde, sosyal kaygının yaygın olarak başka psikolojik problemler (diğer kaygı bozuklukları, alkol ve madde kötüye kullanımı, davranış problemleri, depresyon vb.) ile birlikte görüldüğü saptanmıştır (Chhabra, Bhatia, Gupta, Kumar ve Srivastava, 2009; Cruz, Martins ve Diniz, 2017; Hazen ve Stein, 1995; Pontillo ve diğerleri, 2017). Öte yandan sosyal kaygı yaşayan bireylerin diğer insanlarla ve ailesiyle yetersiz etkileşim ve sınırlı bir paylaşım içinde olduklarına (La Greca ve Lopez, 1998; Mehtalia ve Vankar, 2004), sosyal kaygı nedeniyle kendisine ve çevresine karşı olumsuz ve yıkıcı davranışlar sergileyebildiğine (Canoğulları, 2014; Xu ve diğerleri, 2012; Zorbaz, 2013) ilişkin bulgular yer almaktadır. Sosyal kaygısı yüksek olan bireylerde ortaya çıkan pek çok problem davranışı gösteren yukarıdaki araştırma sonuçlarına benzer şekilde, bu araştırma sonuçlarında da sosyal kaygının alt boyutlarından biri olan olumsuz değerlendirilme kaygısı ile ergenlerde şiddet eğilimi arasında pozitif yönde anlamlı bir ilişki olduğu ortaya çıkmıştır. Bu yönüyle sonuçlar alanyazında var olan araştırma sonuçlarını destekler niteliktedir.

Kimlik gelişimi dönemi olarak da öne çıkan ergenlik sürecinde yaşanan bir diğer önemli zorluk ise bireyin ailesinden bağımsızlaşarak özerk bir ben duygusu geliştirmesiyle ilgilidir. Araştırmanın bir diğer önemli bulgusu; ergenlerin duygusal özerklik ölçeğinin alt boyutları olan 'ebeveyni idealleştirmeme', 'ebeveynden bağımsızlık' ve 'bireyleşme' düzeyi ile şiddet eğilimi puanları arasında negatif yönde anlamlı ilişkiler olduğudur. Başka bir ifade ile ergenlerin duygusal özerklikleri arttıkça şiddet eğilimi puanları azalmaktadır. Ergenlik dönemi kimlik oluşturma ve çok sayıda değişim deneyimi yaşanan kritik bir süreçtir. Böylesine hassas bir zamanda, ebeveynlerden duygusal olarak kopma, depresyon, kaygı, öfke şiddete yol açan faktörleri daha da artırabilir. Bowen (1972) aileden sağlıklı bir şekilde ayrımlaşabilen ve özerk bir kimlik oluşturabilen bireylerin yetişkinlik yaşamlarında daha sağlıklı ilişkiler geliştirebileceğini vurgulamıştır. Ergenlerin büyük bir kısmı için özerk davranabilmek yetişkin olmanın bir parçası olan kimlik kazanmak kadar önemlidir (Noom, Dekovic ve Meeus, 2001).

Literatürdeki bazı araştırmalar da duygusal olarak özerkliğin ergenler arasındaki davranış problemleriyle negatif yönde anlamlı ilişkisi olduğunu göstermiştir (Chou, 2003; Lamborn ve Steinberg, 1993; Ryan ve Lynch, 1989; Sandhu ve Kaur, 2012; Zimmer-Gembeck ve Collins, 2003). Dhillon ve Mehra (2019) yapmış oldukları araştırmada ise duygusal özerkliğin depresyonun önemli bir belirleyicisi olduğunu ortaya koymuştur. Güven ve Aslan (2010), ise lise öğrencilerinin ayrışma-bireyleşme düzeyleri ile okul zorbalığı arasında yine negatif yönde anlamlı bir ilişki olduğunu tespit etmiştir. Ahmad, Rafeh ve Rafique (2018) yaptıkları bir başka araştırmanın sonuçlarına göre duygusal özerklik ve davranış sorunları arasında yine negatif yönde bir ilişki olduğunu ortaya koymuştur.

$\mathrm{Bu}$ araştırmanın sonuçlarına göre duygusal özerklik arttıkça şiddet eğilimi azalmaktadır. Başka bir ifade ile duygusal özerklik şiddet eğiliminin negatif yordayıcısıdır. Bu araştırma sonuçları, mevcut literatürde yapılmış bazı araştırma sonuçları ile benzer bulgulara ulaşıldığını göstermektedir (Chou, 2003; Dhillon, 2014; Lamborn ve Steinberg, 1993; Ranjit ve Natarajan, 2013; Ryan ve Lynch, 1989; Sandhu ve Kaur 2012; Zimmer-Gembeck ve Collins, 2003). Alan 
yazın incelendiğinde yurt dışındaki bazı araştırmacıların duygusal özerkliğin uyum sorunları ile ilişkili olduğunu ifade ettikleri görülmektedir (Beyers ve Goossens, 1999). Bununla birlikte; duygusal özerkliğe sahip bireylerin daha olgun, daha sorumlu ve daha az bağımlı ilişkiler kurduğu (Steinberg, 2007) belirtilmektedir. Türkiye literatürüne bakıldığında ergenlerde duygusal özerklik ile şiddet eğilimine yönelik bir çalışmaya rastlanmamıştır. Araştırma sonuçlarından hareketle birey kimlik gelişimi süreci olan ergenlik döneminde aileden sağ liklı bir biçimde bağımsızlaşma ve özerklik gelişimi olmadığında şiddet eğilimi gibi bazı sağlıksız tutum ve davranışların ortaya çıkabileceği söylenebilir.

Sonuç olarak, bu araştırmada ergenlerde görülen şiddet eğilimi düzeyinin cinsiyet ve anne-baba eğitim düzeyi gibi sosyo-demografik değişkenlere göre farklılaştığı saptanmıştır. Bununla birlikte, ergenlerin sosyal kaygı ölçeği alt boyutu olan 'olumsuz değerlendirilme korkusu' ile şiddet eğilimi puanları arasında pozitif yönde anlamlı bir ilişki olduğu görülürken; duygusal özerklik ölçeğinin alt boyutları olan 'ebeveyni idealleştirmeme', 'ebeveynden bağımsızlık' ve 'bireyleşme' ile şiddet eğilimi puanları arasında negatif yönde anlamlı ilişkiler olduğu görülmüştür. Regresyon analizi sonuçlarına bakıldığında ise, katılımcıların cinsiyet ve anne-baba eğitim düzeyi gibi sosyodemografik değişkenler ile birlikte, sosyal kaygi ölçeği alt boyutu olan 'olumsuz değerlendirilme korkusu' ve duygusal özerklik ölçeği alt boyutları olan 'ebeveyni idealleştirmeme', 'ebeveynden bağımsızlık' ve 'bireyleşme' alt boyutlarının birlikte şiddet eğiliminin önemli yordayıcıları olduğu saptanmıştır.

Ergenlerin şiddet eğilimi göstermesine neden olan olumsuzlukların giderilmemesi durumunda, uzun vadede bireyin ve toplumun ruh sağlığ tehdit altında olabilecektir. Bu anlamda ergenlerin şiddet eğilimlerinin ve ilişkili olduğu değişkenlerin saptanması ve önlenebilmesi açısından, başta aile ve eğitim ortamı da olmak üzere psikolojik danışmanlık hizmetlerinin çok önemli olduğu söylenebilir. Bu çerçevede, şiddet açısından okul düzeyine göre bazı önleyici psikoeğitim programlarının geliştirilmesi ve uygulanması önem arz etmektedir. Bu programlarla birlikte, şiddet davranışı açısından potansiyel teşkil eden öğrenciler ile ilgili ebeveynler, öğretmenler ve öğrencilerle yapılacak olan bireysel ve grupla psikolojik destek hizmetleri şiddetin önlenmesi ve ortadan kalkması konusunda önemli katkılar sağlayabilir. Ergenler, bu dönemde bağımsız olma ve kimliklerini bulma yolunda çok zorlu bir süreçten geçmeye çalışmaktadırlar. Şiddet, birçok faktörün birbiriyle etkileşimi sonucu ortaya çıkan köklü bir problemdir. Bu nedenle şiddetin önlenmesi için okul, aile, toplum, öğrenci ve sosyal kuruluşlarda mücadelenin hep birlikte yer alması problemlerin önlenmesi noktasında yararlı olabilir.

$\mathrm{Bu}$ araştırmanın sonuçları sınırlılıkları çerçevesinde dikkatle değerlendirilmelidir. $\mathrm{Bu}$ araştırmadaki örneklem grubu Orta Anadoluda bir şehir merkezinde öğrenim gören öğrencilerden oluşmaktadır. $\mathrm{Bu}$ çerçevede, araştırma sonuçları, çalışma grubuna katılan bireylerin kişisel görüşlerine dayanmaktadır ve ancak benzeri sosyo-kültürel yapıdaki ergen bireylere genellenebilir. Bu ve benzeri değişkenlerin farklı yaş gruplarıyla ve toplumun farklı kesimlerini temsil eden örneklem gruplarıyla yapılmasının sonuçların genellenebilirliği açısından alana katkı sağlayacağı düşünülmektedir. Bununla birlikte, ergenlerde sosyal kaygı, duygusal özerklik ve şiddet gibi önemli problemlerin nedenlerini daha kapsamlı bir şekilde değerlendirebilmek açısından derinlemesine bilgi toplanan nitel araştırmalar yapılarak alanyazına bu konuda katkı sağlanabilir. Son olarak, ergenlerde şiddet, sosyal kaygı ve otonomi gibi özelliklerin etkilerini araştırmak için boylamsal araştırma tasarımları kullanarak bireyde meydana gelen değişimleri de izleyebilmek ve bu konuda önlemler alabilmek açısından yararlı olacaktır.

\section{Kaynaklar}

Ahmad, S., Rafeh, A. ve Rafique, M. (2018). Relationship between emotional autonomy and behaviour problems among adolescents: Moderating impact of gender. Pakistan Journal of Psychological Research, 33(2), 473-492.

Albano, A. M. ve Hayward. (2004). Social anxiety disorder. T. H. Ollendick (Yay. haz.). Phobic and Anxiety Disorders in Children and Adolescents: A Clinician içinde (ss. 198-235). Cary, NC, USA: Oxford University Press. 
Amerikan Psikiyatri Birliği (2013). Ruhsal bozuklukların tanısal ve sayımsal el kitabı. Beşinci Baskı (DSM-5), (E. Köroğlu, Çev.) Ankara: Hekimler Yayın Birliği.

Aral, N., Ayhan, A., Türkmenler, B. ve Akbıyık, A. (2004). İlköğretim okullarının sekizinci sınıfına devam eden çocukların saldırganlık eğilimlerinin incelenmesi. Çağdaş Eğitim Dergisi, 17(25), 18-24.

Avcı, A. (2010). Aile yapı ve atmosferinin okul şiddetine etkisi. Değerler Eğitim Dergisi, 8(19), 7-52.

Avc1, R. (2006). Şiddet davranışı gösteren ve göstermeyen ergenlerin ailelerinin aile işlevleri, öfke ve öfke ifade tarzları açısından incelenmesi (Yüksek lisans tezi). Çukurova Üniversitesi, Sosyal Bilimler Enstitüsü, Adana.

Ayan, S. (2007). Aile içinde şiddete uğrayan çocukların saldırganlık eğilimleri, Anadolu Psikiyatri Dergisi, 8(3), 206-214.

Aydın, A. ve Tekinsav-Sütçü, S. (2007). Ergenler İçin Sosyal Kaygı Ölçeğinin (ESKÖ) geçerlik ve güvenirliğin incelenmesi. Çocuk, Gençlik ve Ruh Sağllğı Dergisi, 14(2), 79-89.

Başbakanlık Aile Araştırma Kurumu Başkanlığı (1998). Aile içinde ve toplumsal alanda şiddet. Başbakanlık Aile Araştırma Kurumu Başkanlığı Yayınları. Bilim Serisi. Ankara: Yayın No: 113.

Balkıs, M., Duru, E. ve Buluş, M. (2005). Şiddete yönelik tutumların özyeterlik, medya, şiddete yönelik inanç, arkadaş grubu ve okula bağl1lık duygusuyla ilişkisi. Ege Eğitim Dergisi, 6(2), 79-96.

Beck, A. T. (2005). Bilişsel terapi ve duygusal bozukluklar, (A. Türkcan Çev.). İstanbul: Litera Yayincilik.

Beyers, W. ve Goossens, L. (1999). Emotional autonomy, psychosocial adjustment, and parenting: Interactions, moderating, and mediating effects. Journal of Adolescence, 22, 753-769.

Bowen, M. (1972). Toward a differentiation of a self in one's family. J. L. Framo (Yay. haz.), Family Interaction, içinde (ss. 111-173). New York: Springer.

Büyüköztürk, S. (2014). Veri analizi el kitabı (2. Baskı). Pegem Akademi Yayıncılık: Ankara.

Canoğulları, Ö. (2014). İnternet bağımlılık düzeyleri farklı ergenlerin cinsiyetlerine göre psikolojik ihtiyaçları, sosyal kaygıları ve anne baba tutum algılarının incelenmesi, (Yüksek lisans tezi). Çukurova Üniversitesi, Sosyal Bilimler Enstitüsü, Adana.

Chhabra, V., Bhatia, M.S., Gupta, S., Kumar, P. ve Srivastava, S. (2009). Prevalence of social phobia in school-going adolescents in an urban area. Delhi Psychiatry Journal, 12(1), 1825.

Chou, K. L. (2003). Emotional autonomy and problem behavior among Chinese adolescents. The Journal of genetic psychology, 164(4), 473-480.

Cohen, J. (1988). Statistical power analysis for the behavioral sciences (2nd Ed.). Hillsdale, NJ: Lawrence Earlbaum Associates.

Collins, W. A., Gleason, T. ve Sesma, A. (1997). Internalization, autonomy, and relationships: Development during adolescence. J. E. Grusec ve L. Kyczynski (Yay. haz.). Parenting And Children's Internalization of Values, içinde (ss. 78-99). New York: Wiley.

Cruz, E. L., Martins, P. D. ve Diniz, P. R. (2017). Factors related to the association of social anxiety disorder and alcohol use among adolescents: A systematic review. Journal de Pediatria, 93(5), 442-451.

Deniz, M., Çok, F. ve Duyan, V. (2013). Duygusal Özerklik Ölçeği'nin ergenler için uyarlanması ve psikometrik özellikleri. Eğitim ve Bilim, 38(167), 352-363.

Dhillon, R. (2014). Relationship of emotional autonomy with anxiety and depression. Annual International Conference on Cognitive ve Behavioral Psychology, içinde (s. 125).

Dhillon, R. ve Mehra, N. (2019). Hardiness as a moderator in the relationship between emotional autonomy and depression among adolescents. Pakistan Journal of Psychological Research, 34(2), 299-309.

Durmuş, E ve Gürgan, U. (2005). Lise öğrencilerinin şiddet ve saldırganlık eğilimleri. Türk Eğitim Bilimleri Dergisi, 3(3), 253-269. 
Erath, S. A., Flanagan, K. S. ve Bierman, K. L. (2007). Social anxiety and peer relations in early adolescence: Behavioral and cognitive factors. Journal of Abnormal Child Psychology, 35(3), 405-416. doi: 10.1007/s10802-007-9099-2.

Gençoğlu, C., Kumcağız, H. ve Ersanlı, K. (2014). Ergenlerin şiddet eğilimine etki eden ailevi faktörler. Turkish Studies-International Periodical for The Languages, Literature and History of Turkish or Turkic, 9(2), 639-652.

Giles, J. W. ve Heyman, G. D. (2005). Preschoolers' Use of trait-relevant information to evaluate the appropriateness of an aggressive response. Aggressive Behavior, 31(5), 498-509.

Gordon, T. (1999). Etkili ana baba ę̆itimi. (E. Aksay ve B. Özkan, Çev.). İstanbul: Ya-pa Yayınları.

Green, B. S. ve Salkınd J. N. (2010). Using SPSS for windows and macintosh: Analyzing and understanding data. NJ USA: Prentice Hall Press

Güven, M. ve Aslan, S. (2010). The separation-individuation and perceived parenting styles in adolescence. Eurasian Journal of Educational Research, 10(41), 117-132.

Hamarta, E. (2009). Ergenlerin sosyal kaygılarının kişilerarası problem çözme ve mükemmeliyetçilik açısından incelenmesi. İlköğretim Online, 8(3), 729-740.

Hazen, A. L. ve Stein, M. B. (1995). Social phobia. Washington: American Psychiatric Press.

Henning, K., Leitenberg, H., Coffey, P., Bennett, T. ve Jankowski, M. K. (1997). Longterm psychological adjustment to witnessing interparental physical conflict during childhood. Child Abuse and Neglect, 21, 501-515. doi:10.1016/S0145-2134(97)00009-4

Huck, S. W. (2008). Reading statistics and research, 5th Edition. New York: Pearson.

Kalaycı, Ş. (2010). SPSS uygulamalı çok değişkenli istatistik teknikleri. (Beşinci Baskı), Ankara: Asil Yayın Dağıtım.

Karasar, N. (2005). Bilimsel araştırma yöntemi. Ankara: Nobel Yayın.

Karataş, Z. B. (2002). Anne baba saldirganlığ ile lise ögrencilerinin saldırganlığ ilişkinin incelenmesi (Yüksek lisans tezi). Çukurova Üniversitesi, Sosyal Bilimler Enstitüsü, Adana.

Kashdan, T. B. (2007). Social anxiety spectrum and diminished positive experiences: Theoretical synthesis and meta-analysis, Clinical Psychological Review, 27(3), 348-365

Kula, E. (2008). Endüstri meslek lisesi ögrencilerinin umutsuzluk düzeyleri ve saldırganlık durumları arasındaki ilişkinin incelenmesi, (Yüksek lisans tezi). Yeditepe Üniversitesi, Sosyal Bilimler Enstitüsü, İstanbul.

La Greca L. J. ve Lopez, N. (1998) Social anxiety among adolescents: Linkages with peer relations and friendships. Journal of Abnorm Child Psychology, 26(2), 83-94.

Lamborn, S. D. ve Steinberg, L. (1993). Emotional autonomy redux: Revisiting Ryan and Lynch. Child Development, 64(2), 483-499.

Lee, S. J. (2009). Online communication and adolescent social ties: Who benefits more from internet use? Journal of Computer-Mediated Communication, 14(3), 509-531.

Lopez, V. A. ve Emmer, E. T. (2002). Influences of beliefs and values on male adolescents' decision to commit violent offenses. Psychology of Men and Masculinity, 3(1), 28-40. doi: /10.1037/1524-9220.3.1.28.

Mehtalia, K. ve Vankar, G. K. (2004). Social anxiety in adolescents. Indian Journal of Psychiatry, 46(3), 221-227.

Ranjit, L. ve Natarajan, P. (2013). A study on emotional autonomy among Adolescents. Researchjournali's Journal of Sociology, 1(1), 1-8.

Noom, M., Dekovic, M. ve Meeus, W. (2001). Conceptual analysis and measurement of adolescent autonomy. Journal of Youth and Adolescence, 30(5), 577-595.

Pathak, R., Sharma, R. C., Parvan, U. C., Gupta, B. P., Ojha, R. K. ve Goel, N. K. (2011). Behavioural and emotional problems in school going adolescents. Australasian Medical Journal, 4(1), 15-21. doi: 10.4066/AMJ.2011.464

Peterson F. L., Walker, L., Whatt. T. J., Rheinboldt, K., White, C. ve Hogkinson, M. (2003). Evidence-based sexuality education. American Public Health Association. Annual Conference San Francisco, California. 
Pineles, S. L. ve Mineka, S. (2005). Attentional biases to internal and external sources of potential threat in social anxiety. Journal of Abnormal Psychology, 114(2), 314-318.

Pontillo, M., Guerrera, S., Ornella, S., Tata, M. C., Averna, R., Vicari, S. ve Armando, M. (2017). An overview of recent findings on social anxiety disorder in adolescents and young adults at clinical high risk for psychosis. Brain Sciences, 7(10), 1-9.

Ryan, R. M. ve Lynch, J. H. (1989). Emotional autonomy versus detachment: Revisiting the vicissitudes of adolescence and young adulthood. Child Development, 60, 340-356.

Rynerson, B. C. (1997) Violence aganist women, maternity and women's health care, D. L. Lowdermilk ve diğerleri, (Yay. Haz.). Sixth Edition, St.Louis, Wiesbaden: Mosby Year Book.

Sağlam, A. ve İkiz, F. E. (2017). Ortaokul öğrencilerinin şiddet eğilimleri ile okula bağl1lık düzeyleri arasındaki ilişkinin incelenmesi. Elementary Education Online, 16(3), 12351246.

Sandhu, D. ve Kaur, D. (2012). Adolescent problem behaviour in relation to emotional autonomy and parent-child relationship, Canadian Social Science, 8(1), 29-35. doi: 10.3968/j.css. 1923669720120801.1420.

Scharf, S. (2000). Genders differences in adolescent aggression: an analysis of instrumentally. Doctoral dissertation, Central Michigan University, UK.

Silvern, L., Karly, J., Waelde, L., Hodges, W. ve Starek, J. (1995). Retrospective reports of parental partner abuse: relationships to depression, trauma symptoms and selfesteem among college students. Journal of Family Violence, 10(2), 177-202.

Steinberg, L. (2007). Ergenlik. F. Çok (Çev.). Ankara: İmge Kitabevi.

Steinberg, L. ve Silverberg, S. B. (1986). The vicissitudes of autonomy in early adolescence. Child Development, 57, 841-851.

Taşkesen, O. (2011). Güzel sanatlar ve spor liselerinin resim bölümleri ile genel liselerde verilen görsel sanatlar eğitiminin ögrencilerin şiddete yönelik davranışlarına etkileri üzerine bir araştırma, (Doktora tezi). Gazi Üniversitesi, Eğitim Bilimleri Enstitüsü, Ankara.

Tassin, C., Reynaert, C., Jacques, D. ve Zdanowicz, N. (2014). Anxiety disorders in adolescence. Psychiatria Danubina, 26(1), 27-30.

Thomas, S. P. ve Smith, H. (2004). School connectedness, anger behaviors, and relationships of violent and nonviolent American youth. Perspectives in Psychiatric Care, 40(4), 135138.

Wells, A. (2009) Metacognitive therapy for anxiety and depression. New York, The Guilford Press.

Wenzel, A., Graff-Dolezal, J., Macho, M. ve Brendle, J. R. (2005). Communication and social skills in socially anxious and nonanxious individuals in the context of romantic relationships. Behaviour Research and Therapy, 43(4), 505-519.

World Health Organization (WHO), (2002). World report on violence and health summary. Geneva, Switzerland. http://www.who.int/violence_injurypreention/violence/world _report/en/summary_en.pdf.

Xu, Y., Schneier, F., Heimberg, R. G., Princisvalle, K., Liebowitz, M. R., Wang, S. ve Blanco, C. (2012). Gender differences in social anxiety disorder: results from the national epidemiologic sample on alcohol and related conditions. Journal of Anxiety Disorders, 26(1), 12-19. doi: 10.1016/j.janxdis.2011.08.006

Yavuzer, Y. (2013). Ergenlerde saldırganlık ve sosyometrik popülerlik arasındaki ilişkilerin incelenmesi. Kuram ve Uygulamada Eğitim Bilimleri, 13(2), 767-780.

Yılmaz, İ. (2008). Endüstri meslek lisesi öğrencilerinin saldırganlık düzeylerinin çok boyutlu olarak incelenmesi (Yüksek lisans tezi). Yeditepe Üniversitesi, Sosyal Bilimler Enstitüsü, İstanbul.

Zimmer-Gembeck, M. J. (2001). Autonomy in adolescence. J. V. Lerner ve R. M. Lerner (Yay. haz.). Adolescence in America: An Encyclopedia içinde (ss. 79-83). Denver, Co: Abc Clio. 
Zimmer-Gembeck, M. J. ve Collins, W. A. (2003). Autonomy development during adolescence. G. R. Adams ve M. Berzonsky (Yay. haz.), Handbook of Adolescence, içinde (ss. 175204). Oxford: Blackwell.

Zorbaz, O. (2013). Lise öğrencilerinin problemli internet kullanımının sosyal kayg ve akran ilişkileri açısından incelenmesi, (Yüksek lisans tezi). Hacettepe Üniversitesi, Sosyal Bilimler Enstitüsü, Ankara.

\section{Extended Abstract}

\section{Introduction}

Adolescence, which is one of the most important stages in individuals' development process, is a critical process that includes many changes. In this period, the individual is expected to develop a sense of identity in the social and communal arena, as well as to adapt to physical, mental and emotional differentiation. Adolescence is generally defined as a period of developing identity, a healthy sense of autonomy and close and intimate relationships with the environment, and achieving a successful place in society (Steinberg, 2007). The rapid biological and psychological changes that occur during adolescence and the behaviors exhibited by the adolescents especially during the transition from childhood to adulthood mediate adolescents to be accepted by their peers, to gain independence from their parents, to oppose traditional values and norms, to cope with their frustrations and concerns, and to develop their identity and thus to mature (Peterson et al., 2003).

Development of a healthy sense of autonomy by getting independent from parents during adolescence and also determining the factors that cause problems such as social anxiety and violence tendency are important for prevention and intervention works to be done in line with these issues. It is believed that the results of this study will contribute to parents, educators, psychological counselors and researchers in the field in order for the adolescent individual to have a versatile and healthy development process. In this context, the prediction power of social anxiety and emotional autonomy over adolescents' violence tendencies was examined in this study. In addition, whether participants' violence tendency levels differed according to their sociodemographic information such as sex and mother-father education level. Within this general purpose, the following hypotheses were tested in this study:

1. There is a significant relationship between adolescents' social anxiety, emotional autonomy and violence tendency levels experienced.

2. Adolescents' social anxiety level will positively predict violence tendency.

3. Adolescents' emotional autonomy level will negatively predict violence tendency.

\section{Method}

In this study, a correlational survey model was used to examine the relationship between adolescents' social anxiety, emotional autonomy and violence tendency. Correlational survey models are used in studies aiming to determine whether two or more variables change together and the degree of this change (Karasar, 2005). Accordingly, the relationship between adolescents' violence tendency levels, and social anxiety, emotional autonomy and some sociodemographic variables was explained.

The sample group of the study consisted of 7th, 8th, 9th and 10th grade students, aged between 13 and 17 (Age mean: 14.91; standard deviation: 0.93), who were attending school in a city center in Central Anatolia during the 2018-2019 academic year. A total of 613 students, 317 (51\%) females and 296 (49\%) males, participated in the study. The study data was collected using 'Social Anxiety Scale for Adolescents', 'Emotional Autonomy Scale', 'Violence Tendency Scale' and 'Personal Information Form', developed by the researchers. SPSS 22 program was used in the data analysis. Necessary legal permissions were obtained from the provincial directorate of national education in Niğde to collect the study data. The determined scales were administered to students during the second semester of the 2018-2019 academic year by the researchers. During the implementation of the scales, the scales were administered to the students during the school 
guidance hours and in their own classrooms after talking to the school administrators and the school psychological counselor. This process took an average of thirty minutes.

Within the scope of this study, in the statistical analysis of the data, whether or not adolescents' violence tendency scores differed according to sex and mother-father education level was examined by t-test and one-way analysis of variance. Later, Pearson Moments Multiplication Correlation Coefficient and Hierarchical Regression Analysis statistical analysis was employed to determine the relationship between students' violence tendency scale scores, and social anxiety scale and emotional autonomy scale for adolescents scores.

\section{Result and Discussion}

As a result, it was found that adolescents' violence tendency levels differed according to sociodemographic variables such as sex and mother-father education level. In addition, while there was a positive significant relationship between the 'fear of negative evaluation' sub-dimension of social anxiety scale for adolescents and violence tendency scores, there were negative significant relationships between 'parental deidealization', 'nondependency on parents' and 'individuation' sub-dimensions of emotional autonomy scale and violence tendency scores. According to the results of the regression analysis, it was determined that the socio-demographic variables such as sex and mother-father education level, 'fear of negative evaluation' sub-dimension of social anxiety scale, and 'parental deidealization' and 'nondependency on parents' and 'individuation' sub-dimensions of the emotional autonomy scale were all significant predictors of violence tendency.

Adolescence is an important development period in which many changes occur in terms of relationships, physical appearance, emotional development and mental capacity. In literature regarding adolescents, there are no studies directly examining the relationship between social anxiety, emotional autonomy and violence tendency. According to literature, many factors such as life histories, family problems, individual characteristics and effects of the school environment may be some of the basic factors that push adolescents to violence. In the long term, the mental health of the individual and the society may be under threat if the negativities that cause adolescents to show violence tendencies are not dissipated. In this sense, it can be said that family and education environment, and psychological counseling services are very important in terms of determining and preventing adolescents' violence tendencies and related variables.

In this context, in terms of violence, it is important to develop and implement some preventive psychoeducational programs according to school level. Along with these programs, individual psychological support services that will be conducted with parents, teachers and students regarding students constituting potential threat in terms of violent behavior can make important contributions to preventing and eliminating violence. Adolescents are trying to go through a very difficult process of being independent and finding identity during this period. Violence is a rooted problem caused by the interaction of many factors. For this reason, including school, family, society, student and social institutions together in the struggle in preventing violence can be beneficial in preventing problems.

The results of this study should be carefully evaluated within the framework of its limitations. The sample group in this study consists of students attending school in a city center in Central Anatolia. In this context, the study results are based on participating individuals' personal opinions and can only be generalized to adolescent individuals with similar sociocultural structure. It is believed that conducting these and similar variables with different age groups and sample groups representing different segments of the society will contribute to the field in terms of generalizability of the results. Furthermore, in order to evaluate the causes of important problems such as social anxiety, emotional autonomy and violence in adolescents, indepth qualitative studies can contribute to literature by gathering in-depth information. Finally, using longitudinal research designs to investigate the effects of characteristics such as violence, social anxiety and autonomy in adolescents will be useful in terms of monitoring changes in the individual and taking precautions in this regard. 